\title{
KONSEP HAK MENGUASAI NEGARA TERHADAP TANAH DALAM HUKUM TANAH (UUPA) DAN KONSTITUSI
}

\section{NI LUH ARININGSIH SARI}

\author{
Fakultas Hukum Universitas 45 Mataram
}

liliksari72@Gmail.com

\begin{abstract}
ABSTRAK
Konsep Hak Menguasai Negara Terhadap Tanah dalam Hukum Tanah (UUPA) dan Konstitusi merupakan hal yang perlu di perjelas berdasarkan hukum. Jenis penelitian dalam penelitian ini adalah penelitian normatif yaitu penelitian terhadap azas-azas hukum yang terkait dengan konsep hak menguasai Negara terhadap tanah dilihat dari aspek Undang-Undang Pokok Agraria dan Konstitusi UUD Negara Republik Indonesia Tahun 1945. Metode pendekatan yang dipergunakan dalam penelitian ini adalah pendekatan perundang-undangan (the statute approach), Pendekatan konseptual (conceptual approach) yaitu memanfaatkan pandangan dan pemikiran para ahli yang berkenaan dengan konsep negara hukum dan pendekatan sejarah (historical approach) dilakukan dengan menelaah latar belakang apa yang mendasari suatu perkembangan pengaturan penerapan hak menguasai Negara. Hasil kajian menunjukkan bahwa konsep hak menguasai Negara yang diatur dalam UUD 1945 dan UUPA, berbeda dengan hubungan hukum yang bersifat kepemilikan antara Negara dengan tanah berdasarkan asas Domeinverklaring yang diatur dalam Hukum Tanah Administrasi Pemerintahan Hindia Belanda yang telah dicabut dalam UUPA. Asas Domeinverklaring bertentangan dengan kesadaran hukum rakyat Indonesia dan asas dari Negara yang merdeka dan modern khususnya pada konstitusi UUD 1945 yang mengatur tentang penguasaan Negara terhadap seluruh sumber daya agraria pada hakikatnya diperuntukkan untuk sebesarbesarnya kemakmuran rakyat (Pasal 33 ayat (3)).
\end{abstract}

Kata kunci: Konsep Hak Menguasai Negara

\section{ABSTRACT}

The concept of the State's Right to Control over Land in Land Law (UUPA) and the Constitution are things that need to be clarified based on law. The type of research in this research is normative research, namely research on legal principles related to the concept of the State's right to control over land seen from the aspects of the Basic Agrarian Law and the 1945 Constitution of the Republic of Indonesia. The approach method used in this research is the statutory approach (the statute approach), the conceptual approach, which utilizes the views and thoughts of experts regarding the concept of the rule of law and the historical approach is carried out by examining what background. which underlie a development of the implementation of the right to control the State. The results of the study show that the concept of the right to control of the State which is regulated in the 1945 Constitution and the UUPA, is different from the legal relationship which is ownership between the State and land based on the Domeinverklaring principle which is regulated in the Land Law for the Administration of the Dutch East Indies Government which has been revoked in the UUPA. The principle of Domeinverklaring contradicts the legal awareness of the Indonesian people and the principles of an independent and modern State, especially in the 1945 Constitution which regulates State control of all agrarian resources which are essentially intended for the greatest prosperity of the people (Article 33 paragraph (3)).

Keywords: Concept of State Control Rights 


\section{PENDAHULUAN}

Tanah merupakan salah satu aset negara Indonesia yang sangat mendasar, karena negara dan bangsa hidup dan berkembang di atas tanah. Masyarakat Indonesia memposisikan tanah pada kedudukan yang sangat penting, karena merupakan faktor utama dalam peningkatan produktivitas agraria. Meskipun tanah dianggap sebagai sumber daya utama dalam masyarakat Indonesia, ternyata di masyarakat, nilai (value) tanah justru mempunyai makna yang lebih luas dibandingkan dengan wujud fisik tanah, karena nilai tanah terkait dengan aspek ekonomi, dan sosial. Dalam perspektif ekonomi tanah adalah salah satu sumber agraria yang paling penting disamping sumber daya lain, misalnya modal (capital) dan tenaga kerja (berupa ketrampilan). Dalam perspektif sosial tanah mempunyai fungsi sosial, sehingga semakin banyak tanah yang dimiliki oleh seseorang maka makin tinggi status sosial orang tersebut (Alting, 2010).

Tanah merupakan kekayaan alam yang dikuasai negara dan dipergunakan sebesar-besarnya kesejahteraan rakyat, hal ini dinyatakan Pasal 33ayat (3) UUD 45, yang dipertegas kembali dalam Pasal 2 ayat (1) Undangundang Nomor 5 Tahun 1960 tentang Dasar-Dasar Pokok Agraria dinyatakan; Atas dasar ketentuan dalam Pasal 33 ayat 3 Undang-undang Dasar dan hal-hal sebagaimana yang dimaksud dalam Pasal 1, bumi, air dan ruang angkasa, termasuk kekayaan alam yang terkandung didalamnya itu pada tingkatan tertinggi dikuasai oleh negara, sebagai organisasi kekuasaan. Memaknai rumusan pasal tersebut memberikan kewenangan kepada negara untuk mengatur pemanfaatan hak-hak atas tanah diwilayah Indonesia. Artinya negara mempunyai kewenangan untuk mengatur, merencanakan serta mengendalikan penguasaan dan pemilikan hak atas tanah. Kewenangan negara menguasai hak atas tanah diperoleh karena permasalahan pertanahan tidak semua dapat diselesaikan sendiri oleh masyarakat, sehingga hak kekuasaan negara atas tanah merupakan pelengkap terhadap hak-hak atas tanah yang dikuasai oleh masyarakat.

Hal ini sebagaimana ditegaskan Frans Magnis Soeseno dalam Ida Nurlinda bahwa: Fungsi Negara dalam penyelenggaraan sebagian kepentingan masyarakat itu hanyalah bersifat melengkapi. Dalam hal masyarakat dapat menyelesaikan kepentingan/masalahnya sendiri, dan selama hal itu tidak bertentangan dengan kepentingan/hak pihak lain, maka campur tangan Negara tidak diperlukan (Nurlinda, 2009). Hak menguasai negara adalah suatu kewenangan atau wewenang formal yang ada pada negara dan memberikan hak kepada negara untuk bertindak baik secara aktif maupun pasif dalam bidang pemerintahan negara, dengan kata lain wewenang negara tidak hanya berkaitan dengan wewenang pemerintahan semata, akan tetapi meliputi pula semua wewenang dalam rangka melaksanakan tugasnya (Ilmar, 2012).

Tanpa adanya penguasaan Negara, maka tidak mungkin tujuan Negara yang telah ditetapkan dalam konstitusi atau UUD dapat diwujudkan, namun demikian penguasaan oleh Negara itu tidak lebih dari semacam "penguasaan" kepada Negara yang disertai dengan persyaratan tertentu, sehingga tidak boleh digunakan secara sewenang-wenang yang dapat berakibat pelanggaran hukum kepada masyarakat.

Pada dasarnya pemberian kekuasaan bisa dibedakan menjadi dua macam, yaitu :

a. Pemberian kekuasaan yang sifatnya "atributif". Pemberian kekuasaan semacam ini disebut sebagai pembentukan kekuasaan, karena dari keadaan yang belum ada menjadi ada. Kekuasaan yang timbul karena pembentukan ini sifatnya asali ( oorspronkelijk) . pada pembentukan kekuasaan semacam ini menyebabkan adanya kekuasaan baru.

b. Pemberian kekuasaan yang sifatnya "derivatif". Pemberian kekuasaan ini disebut juga sebagai "pelimpahan kekuasaan", karena dari kekuasaan yang telah ada dialihkan kepada badan hukum publik lain. Oleh karena itu sifatnya derivatif ( afgeleid).

Secara formal, kewenangan Pemerintah untuk mengatur bidang pertanahan tumbuh dan mengakar dari Pasal 33 ayat (3) Undang-undang Dasar 1945 yang menegaskan bahwa : "bumi, air, dan kekayaan alam yang terkandung didalamnya dikuasai oleh Negara untuk pergunakan bagi sebesar-besar kemakmuran rakyat".Sebelum amandemen Undang-undang Dasar 1945, pasal 33 ayat 3 tersebut dijelaskan dalam penjelasan Pasal 33 alinea 4 yang berbunyi : "Bumi dan air dan kekayaan alam yang terkandung didalamnya adalah pokokpokok kemakmuran rakyat. Sebab itu harus dikuasai oleh Negara dan dipergunakan untuk sebesar-besarnya kemakmuran rakyat".Kemudian dituntaskan secara kokoh didalam undang-undang Nomor 5 Tahun 1960 tentang peraturan dasar pokok-pokok Agraria (Lembaran Negara 1960-104 atau disebut juga Undang-undang pokok agraria UUPA) (Yamin \& Lubis, 2008). 
Sedangkan pengertian menurut Kamus Besar Bahasa Indonesia kata "menguasai" berarti kedudukan berkuasa atas sesuatu atau memegang kekuasaan atas sesuatu. Dengan demikian hak menguasai negara jika dimaknai menurut pengertian kamus adalah kekuasaan negara atas sumber daya alam Indonesia. Sehingga bila dihubungkan dengan penjelasan Pasal 2 ayat (1) UUPA yang secara khusus memberikan pengertian hak menguasai atas tanah adalah dinyatakan: sesuai dengan pangkal pendirian tersebut diatas perkataan "dikuasai", dalam pasal ini akan tetapi adalah pengertian, yang memberi wewenang kepada negara sebagai organisasi kekuasaan dari bangsa Indonesia.

\section{Rumusan Masalah :}

Adapun rumusan masalah dalam penelitian ini yaitu "Bagaimanakah konsep Hak Menguasai Negara Terhadap Tanah dalam Hukum Tanah (UUPA) dan Konstitusi ?"

\section{Tujuan Penelitian}

Tujuan penelitian ini untuk mendeskripsikan konsep hak menguasai Negara Terhadap Tanah dalam Hukum Tanah (UUPA) dan Konstitusi

\section{METODE PENELITIAN}

Jenis penelitian dalam penelitian ini adalah penelitian normatif yaitu penelitian terhadap azas-azas hukum yang terkait dengan konsep hak menguasai Negara terhadap tanah dilihat dari aspek Undang-Undang Pokok Agraria dan Konstitusi UUD Negara Republik Indonesia Tahun 1945.

Metode pendekatan yang dipergunakan dalam penelitian ini adalah pendekatan perundang-undangan (the statute approach), Pendekatan konseptual (conceptual approach) yaitu memanfaatkan pandangan dan pemikiran para ahli yang berkenaan dengan konsep negara hukum dan pendekatan sejarah (historical approach) dilakukan dengan menelaah latar belakang apa yang mendasari suatu perkembangan pengaturan penerapan hak menguasai Negara. Tehnik yang dipergunakan dalam pengumpulan bahan hukum adalah dengan studi dokumen yakni melakukan pengkajian terhadap data kepustakaan (data sekunder) yang relevan dengan obyek penelitian yang meliputi bahan hukum pimer, sekunder dan tersier baik terhadap peraturan perundang-undangan, buku-buku referensi maupun kamus-kamus hukum. Selanjutnya dianalisis secara deskriptif kualitatif.

\section{HASIL DAN PEMBAHASAN}

Undang-Undang Nomor 5 Tahun 1960 tentang Peraturan Dasar Pokok-Pokok Agraria (selanjutnya disebut UUPA) merupakan penjabaran Pasal 33 ayat (3) Undang-Undang Dasar 1945. UUPA berisi peraturan dasar yang memuat hal-hal pokok tentang dasar dan arah kebijakan politik agraria nasional, khususnya hubungan manusia dengan tanah.

Beberapa pokok ketentuan dalam UUPA adalah:

1. Pernyataan bahwa bumi, air dan ruang angkasa dalarn wilayah Indonesia adalah kesatuan tanah air dari seluruh rakyat Indonesia yang bersatu sebagai bangsa Indonesia (Pasal 1 ayat (1)). Hubungan yang tercipta adalah bersifat abadi (Pasal 1 ayat (3));

2. Pernyataan bahwa bumi, air dan ruang angkasa yang demikian itu sebagai karunia Tuhan Yang Maha Esa dan merupakan kekayaan nasional (Pasal 1 ayat (2));

3. Pernyataan bahwa bumi, air dan ruang angkasa pada tingkatan tertinggi dikuasai oleh negara sebagai organisasi kekuasaan seluruh rakyat (Pasal 2 ayat (1));

4. Perintah bahwa hukum agraria yang mengatur tentang bumi, air dan ruang angkasa harus mewujudkan penjelmaan dari asas kerohanian negara dan cita-cita bangsa yang terkandung dalarn Pancasila, (Penjelasan Umum UUPA) dalam wadah negara hukum yang berkedaulatan rakyat (Pasal2 ayat (3));

5. Perintah agar negara: a) mengatur dan menyelenggarakan peruntukan, penggunaan, persediaan dan pemeliharaan bumi, air dan ruang angkasa; b) menentukan dan mengatur hubungan-hubungan hukum antara 
orang-orang dengan bumi, air dan ruang angkasa; c) menentukan dan mengatur hubungan hubungan hukum antara orang-orang dan perbuatan perbuatan hukum mengenai bumi, air dan ruang angkasa (Pasal2 ayat (2));

6. Perintah agar wewenang yang bersumber dari hak menguasai negara tersebut digunakan untuk mencapai sebesar-besar kemakrnuran rakyat;

7. Perintah agar negara melalui pemerintah: a) mengatur hubungan-hubungan hukurn antara orang, masyarakat dan negara (Pasal 11 ayat (1)); b) membuat aturan untuk mengusahakan tanah secara bersama berdasar kerjasama dan untuk kepentingan bersama (Pasal 12); c) membuat aturan yang bertujuan dapat meningkatkan kemakmuran rakyat serta menjamin bagi setiap warga negara Indonesia derajat hidup yang sesuai dengan martabat manusia baik bagi dirinya maupun keluarganya (Pasal 13 ayat (1)); d) membuat aturan yang melarang penggunaan tanah melampaui batas, mencegah adanya unsure pemerasan, mencegah adanya unsur monopoli serta aturan mengenai hak sosial dalam penggunaan tanah serta kewajiban untuk mengusahakan sendiri penguasaan tanah dan mencegah kerusakan (Pasal 15);

8. Pemerintah juga diharuskan untuk membuat rencana umum mengenai persediaan, peruntukan dan penggunaan tanah untuk kepentingan negara, kepentingan peribadatan dan keperluan suci lainnya serta untuk kepentingan pusat-pusat kehidupan masyarakat, sosial, budaya dan lain-lain kesejahteraan, untuk produksi pertanian, perikanan dan peternakan termasuk jaminan social perburuhan dengan memperhatikan golongan ekonomi lemah serta perkembangan industri, transmigrasi dan pertambangan (Pasal 13 dan 14 ayat (1))

9. Pemerintah secara koordinatif dan berjenjang harus bekerjasama untuk menjabarkan tugas dan fungsi kewenangan yang diembannya berdasarkan atas asas-asas (Pasal 14ayat (2) dan (3)) (Harsono, 2008).

Dikalangan para ahli muncul gagasan untuk membatasi wewenang negara yang bersumber pada hak menguasai oleh negara atas tanah.yaitu Maria Sriwulandari menghendaki agar kewenangan negara atas tanah dibatasi oleh dua hal :

a. Pembatasan Oleh Undang-Undang Dasar Pada prinsipnya hal-hal yang diatur oleh negara tidak boleh berakibat terhadap pelanggaran hak-hak dasar manusia yang dijamin oleh Undang-Undang Dasar.

b. Pembatasan yang Bersifat Substantif Sesuai dengan Pasal 2 ayat (3) UUPA, maka semua peraturan pertanahan harus ditujukan untuk terwujudnya sebesar-besarnya kemakmuan rakyat, sedangkan ruang lingkupnya pengaturan pertanahan dibatasi oleh Pasal 2 ayat (2) UUPA. Disamping relevansi, maka kewenangan pembuatan kebijaksanaan tidak dapat didelegasikan kepada organisasi swasta, karena yang diatur itu berkaitan dengan kesejahteraan umum yang sarat dengan misi pelayanan. Pihak swasta merupakan bagian dari masyarakat yang ikut diwakili kepentingannya dan oleh karena itu tidak dimungkinkan mengatur karena hal itu akan menimbulkan konflik kepentingan (Sumardjono, 2009).

Maria Rita Ruwiastuti, mengemukakan analisis kritis tetntang hubungan antara hak menguasai oleh negara dengan hak-hak adat sebagai berikut: "Politik hukum agraria yang terkandung dalam Undang-Undang Pokok Agraria 1960 tersebut sejak semula telah menetapkan keluasan kewenangan Negara dalam menguasai sumbersumber agraria di seluruh wilayah negeri ini. Kewenangan yang kemudian disebut dengan hak menguasai dari negara (HMN) itu sama sekali tidak dapat diperbandingkan dengan hak-hak keperdataan ( privaatrechtelijk) itu hanya mungkin dipegang oleh sebuah badan kenegaraan.

Sesuai dengan Penjelasan UUPA, maka Hak Menguasai Negara tersebut meliputi atas bumi, air dan ruang angkasa, jadi baik yang sudah ada hak seseorang maupun yang tidak/belum ada. Kekuasaan Negara mengenai tanah yang sudah dipunyai orang dengan sesuatu hak dibatasi oleh isi hak itu, artinya sampai seberapa jauh Negara memberi kekuasaan kepada yang mempunyai hak untuk menggunakan haknya, sampai disitulah batas kekuasaan Negara tersebut.

Konsorsium Pembaruan Agraria (KPA) menggugat konsep hak menguasai tanah oleh negara yang dimanfaatkan oleh pemerintah untuk melakukan sejumlah pengingkaran terhadap hak-hak masyarakat hukum adat atas sumber daya alam yang ada di wilayah ( tanah ulayatnya ), dan memanfaatkannya untuk memberi ruang gerak bagi perusahaan-perusahaan besar dengan mengatasnamakan pembangunan. KPA menghendaki hak menguasai tanah oleh negara dibatasi secara tegas, agar hak ini mempunyai batas-batas yang jelas baik secara konseptual maupun implementasinya. KPA memberi rekomendasi sebagai berikut :

1. Sudah selayaknya, proses konsentrasi penguasaan sumber-sumber agraria di satu pihak dan sengketa agraria mendorong para pembentuk kebijakan untuk melakukan pembaruan hukum pertanahan.

2. Bahwa penyebab pokok dari konsentrasi penguasaan tanah dan sengketa agraria adalah penggunaan suatu "Kekuasaan Negara Atas Tanah" yang berlebihan, yang diwakili oleh konsep politik hukum hak menguasai 
oleh negara atas tanah. pembatasan itu bisa dilakukan terhadap hak menguasai negara atas tanah. KPA mengusulkan adanya pembatasan hak menguasai oleh negara atas tanah. pembatasan itu dapat dilakukan dengan me-review bebrbagai Undang-Undang yang berhubungan dengan "Kekuasaan Negara Atas Tanah" yang terlampau besar, yang di dalamnya tentunya termasuk UUPA.

Kewenangan Negara terhadap tanah, menurut Boedi Harsono sebagaimana yang dikutip oleh Arie Sukanti, bahwa Negara diberikan kewenangan untuk mengatur tanah dan unsur-unsur sumber daya alam lainnya yang merupakan kekayaan nasional. Dalam hal ini Negara berwenang mengatur persediaan, perencanaan, penguasaan, dan penggunaan tanah serta pemeliharaan tanah atas seluruh tanah di wilayah Republik Indonesia dengan tujuan agar dapat dipergunakan untuk sebesar-besarnya kemakmuran rakyat. Kewenangan tersebut dilaksanakan Negara dalam kedudukannya sebagai organisasi kekuasaan seluruh rakyat Indonesia atau kedudukan sebagai badan penguasa.

Menurut Jasim Hamidi pengertian penguasaan dan menguasai dapat dipakai dalam arti fisik juga dalam arti yuridis. Dalam arti fisik secara nyata pemegang hak menguasai tanah (tanah dalam penguasaan). Penguasaan dalam arti yuridis dilandasi oleh "hak" yang dilindungi oleh hukum dan umumnya memberi kewenangan kepada pemegang hak untuk menguasai secara fisik tanah yang menjadi haknya. Tetapi ada juga penguasaan yuridis yang biarpun memberi kewenangan untuk menguasai tanah haknya secara fisik, pada kenyataannya penguasaan fisiknya dilakukan pihak lain.

Hubungan hukum antara negara dengan bumi, air dan ruang angkasa menurut Notonegoro yang menetapkan adanya tiga macam bentuk hubungan sebagai berikut:

a. Negara sebagai subjek, diberi kedudukan tidak sebagai perorangan tetapi sebagai negara. Dengan demikian, negara sebagai badan kenegaraan, badan yang publiekrechtelijk. Dalam bentuk ini negara tidak mempunyai kedudukan yang sama dengan perorangan.

b. Negara sebagai obyek, yang dipersamakan dengan perorangan sehingga hubungan antara negara dengan bumi dan lain sebagainya itu "sama" dengan hak perorangan atas tanah.

c. Hubungan antara negara "langsung" dengan bumi dan sebagainya tidak sebagai subjek perorangan dan tidak dalam kedudukannya sebagai negara yang memiliki, tetapi sebagai negara yang menjadi personifikasi dari seluruh rakyat sehingga dalam konsep ini negara tidak lepas dari rakyat. Negara hanya menjadi pendiri dan pendukung kesatuan-kesatuan rakyat.

Menurut Iman Soetiknjo bahwa Negara mempunyai kewenangan baik kedalam maupun keluar yaitu;

a. Membuat suatu rencana umum mengenai persediaan, peruntukan, dan penggunaan bumi, air, dan ruang angkasa serta kekayaan alam yang terkandung di dalamnya untuk keperluan yang bersifat politis, ekonomis, dan sosial (Pasal 14 ayat (1) UUPA), sedangkan pemerintah daerah juga harus membuat perencanaannya sesuai dengan rencana pemerintah pusat (Pasal 14 ayat (2) UUPA).

b. Menentukan adanya macam-macam hak atas permukaan bumi yang dapat diberikan dan dipunyai oleh perorangan (baik sendiri maupun bersama-sama)/badan hukum (Pasal 4 UUPA). Hal ini berarti bahwa bagi perorangan/ badan hukum tertentu dimungkinkan mempunyai hak milik atas tanah.

c. Berusaha agar sebanyak mungkin orang mempunyai hubungan dengan tanah,dengan menentukan luas maksimum tanah yang boleh dimiliki/dikuasai perorangan (Pasal 7 dan 17 UUPA), mengingat tiap-tiap WNI mempunyai kesempatan yang sama untuk memperoleh suatu hak atas tanah serta mendapat manfaat dan hasilnya, baik bagi diri sendiri maupun keluarganya (Pasal 9 ayat (2) UUPA).

d. Menentukan bahwa setiap orang/badan hukum yang mempunyai suatu hak atas tanah, mengusahakan tanah itu sendiri, dengan beberapa perkecualian (Pasal 10 UUPA). Hal ini untuk menjaga jangan sampai ada tanah absente.

e. Berusaha agar tidak ada tanah telantar dengan menegaskan bahwa semua hak atas tanah berfungsi sosial, dan mencegah kerusakannya merupakan kewajiban siapa saja yang mempunyai hak atas tanah (Pasal 6 dan Pasal 15 UUPA).

f. Mengatur hubungan-hubungan hukum antara orang-orang dan perbuatan-perbuatan hukum mengenai bumi, air, dan ruang angkasa. Misalnya hak guna usaha, hak guna bangunan, sewa-menyewa, sebagaimana tersebut dalam Pasal 16 UUPA.

g. Mengatur pembukaan tanah, pemungutan hasil hutan (Pasal 46 UUPA) dan penggunaan air dan ruang angkasa (Pasal 47,48 UUPA).

h. Mengatur pengambilan kekayaan alam yang terkandung dalam bumi, air, dan ruang angkasa (Pasal 8 UUPA). 
i. Mengadakan pendaftaran tanah di seluruh wilayah Republik Indonesia, untuk menjamin kepastian hukum (Pasal 19 UUPA).

Selanjutnya kewenangan negara keluar dapat melakukan sebagai berikut :

a. Menegaskan bahwa hubungan bangsa Indonesia dengan bumi, air, dan ruang angkasa dalam wilayah Indonesia sebagai karunia Tuhan Yang Maha Esa, dan karenanya bersifat abadi (Pasal 1 ayat (3) UUPA). Hal ini berarti hubungan tersebut tidak dapat diputus oleh siapa pun.

b. Menegaskan bahwa orang asing (bukan WNI) tidak dapat mempunyai hubungan penuh dan kuat dengan bumi, air, ruang angkasa dan kekayaan alam yang terkandung di wilayah Indonesia. Hanya WNI yang dapat mempunyai hubungan yang sepenuhnya dan terkuat di seluruh wilayah Indonesia (Pasal 21 UUPA).

Sedangkan menurut SW. Soemardjono bahwa: “..di Indonesia, dalam konsep negara menguasai, negara yang memperoleh kewenangan dari seluruh rakyat (bangsa) Indonesia, diberi kedudukan sebagai badan penguasa yang pada tingkatan tertinggi berwenang untuk mengatur pemanfaatan tanah dalam arti luas serta menentukan dan mengatur hubungan pemenfaatan dan perbuatan hukum berkenaan dengan tanah.Sebagai penerima kuasa, maka segala tindakan negara yang berkaitan dengan pembuatan kebijakan dan pengawasan atas terlaksananya segala peraturan dan kebijaksanan itu harus dipertanggung jawabkan kepada masyarakat. Dalam prinsip "Negara menguasai", maka dalam hubungan antara negara dan masyarakat, kedudukan masyarakat tidak dapat disubordinasikan berada di bawah negara, karena negara justru menerima kuasa dari masyarakat untuk mengatur tentang peruntukan, persediaan dan penggunaan tanah, serta hubungan hukum dan perbuatan hukum yang bersangkutan dengan tanah.

Konsep Hak Menguasai Negara yang diatur dalam UUD 1945 dan UUPA, berbeda dengan hubungan hukum yang bersifat kepemilikan antara Negara dengan tanah berdasarkan asas Domeinverklaring yang diatur dalam Hukum Tanah Administrasi Pemerintahan Hindia Belanda yang telah dicabut dalam UUPA. Asas Domeinverklaring bertentangan dengan kesadaran hukum rakyat Indonesia dan asas dari Negara yang merdeka dan modern khususnya pada konstitusi UUD 1945 yang mengatur tentang penguasaan Negara terhadap seluruh sumber daya agraria pada hakikatnya diperuntukkan untuk sebesar-besarnya kemakmuran rakyat (Pasal 33 ayat (3)).

Dengan demikian dapat diketahui, meskipun negara diberi kewenangan (yang sangat luas) atas tanah, namun sesungguhnya dibatasi secara hukum untuk mewujudkan kemakmuran rakyat sesuai dengan tujuan berbangsa dan bernegara. Pengertian hak menguasai negara yang "dibatasi oleh hukum" dalam implementasinya oleh aparat penguasa, pengusaha terlebih lagi masyarakat belum memahami sepenuhnya makna yang terkandung dalamnya. Juga hal-hal yang menyangkut peraturan perundang-undangan yang tentang hak atas tanah dan pengelolaan sumber daya agraria.

Pasal 2 UUPA yang merupakan aturan pelaksanaan pasal 33 ayat (3) UUD 1945 dijelaskan pngertian hak menguasai sumber daya alam oleh negara sebagai berikut :

1. Atas dasar ketentuan Pasal 33 ayat (3) UUD 1945 dan hal-hal yang sebagaimana dimaksud dalam pasal 1 bumi, air, dan ruang angkasa termasuk kekayaan alam yang terkandung di dalamnya itu pada tingkatan tertinggi dikuasai oleh negara, sebagai organisasi kekuasaan seluruh rakyat. Hak menguasai negara tersebut dalam ayat (1) pasal ini memberikan wewenang untuk : a.Mengatur dan menyelenggarakan peruntukan, penggunaan, persediaan dan pemeliharaan bumi, air dan ruang angkasa. b.Menentukan dan mengatur hubungan-hubungan hukum antara orang-orang dengan bumu, air, dan ruang angkasa. c. Menentukan dan mengatur hubungan-hubungan hukum antara orang-orang dan perbuatan-perbuatan hukum yang mengenai bumi, air dan ruang angkasa

2. Wewenang yang bersumber pada hak menguasai dari negara tersebut Pada pasal 33 ayat (2), digunakan sebesar-besarnya untuk kemakmuran rakyat dalam arti kebangsaan kesejahteraan, kemerdekaan dalam masyarakat, dan negara hukum indonesia yang merdeka, berdaulat adil dan makmur.

3. Hak menguasai dari negara tersebut di atas pelaksaannya dapat dikuasakan kepada daerah-daerah, swasta dan masyarakat-masyarakat hukum adat, sekedar diperlukan dan tidak bertentangan dengan kepentingan nasional, menurut ketentuan-ketentuan peraturan yang berlaku.

Berdasarkan pasal 2 UUPA dan penjelasannya tersebut, menurut konsep UUPA, pengertian "dikuasai" oleh negara bukan berarti dimiliki, melainkan hak yang memberi kewenangan pada negara untuk menguasai hal tersebut di atas (Harsono, 200). Menurut Samun Ismaya, tata susunan hak penguasaan atas tanah yaitu : 
1. Hak Bangsa Indonesia yang termuat dalam ketentuan UUPA yang mengatakan bahwa "Seluruh wilayah Indonesia adalah kesatuan tanah air dari seluruh rakyat Indonesia yang bersatu sebagai bangsa Indonesia".

2. Hak Menguasai Negara yang termuat dalam UUD 1945 pada Pasal 33 ayat (3) juga pada UUPA yang termuat Pasal 2.

3. Hak-hak individu yang terdiri dari :

a. Hak atas tanah yaitu hak atas tanah primer yang terdiri dari hak milik, hak guna bangunan, hak guna usaha, serta hak pakai yang diberikan oleh negara, hak atas tanah sekunder terdiri dari hak guna bangunan, hak pakai yang diberikan oleh pemilik tanah, hak gadai, hak usaha bagi hasil, hak menumpang, hak sewa dan lain-lain.

b. Wakaf dan Hak jaminan atas tanah (Ismaya, 2011)."

Pemaknaan Hak Menguasai Negara oleh Mahkamah Konstitusi bahwa Hak Mengusai Negara (HMN) seharusnya diletakkan pada dimensi filosofis yang tidak hanya memberikan kesempatan yang sama bagi setiap individu untuk menguasai tanah, melainkan juga memastikan bahwa individu-individu yang berada dalam posisi yang tidak menguntungkan memperoleh perlakuan yang berbeda dengan individu yang kedudukan sosial dan ekonominya lebih baik. Petani penggarap, orang-orang miskin yang tidak memiliki tanah, dan masyarakat hukum adat adalah beberapa contoh masyarakat yang perlu memperoleh perhatian dan perlakuan khusus yang menjamin hak-hak mereka atas tanah, sehingga dapat memiliki kedudukan yang setara dengan perusahaanperusahaan besar.

MK memberikan catatan penting mengenai dasar-dasar pengaturan dalam rangka pengalokasian dan pendistribusian sumber-sumber kehidupan bangsa untuk kesejahteraan: Dalam ketentuan konstitusional sebagai dasar-dasar pengaturan dalam rangka pengalokasian sumber-sumber kehidupan bangsa untuk kesejahteraan, termasuk di dalamnya sumber daya alam, seperti hutan, terdapat hal penting dan fundamental. Pertama, penguasaan Negara terhadap cabang produksi yang penting bagi negara dan yang menguasai hajat hidup orang banyak. Kedua, penguasaan negara terhadap bumi dan air dan kekayaan alam yang terkandung di dalamnya. Ketiga, penguasaan negara terhadap sumber daya tersebut, termasuk di dalamnya sumber daya alam, dimaksudkan supaya negara dapat mengatur dalam rangka pengelolaan terhadap sumber daya kehidupan tersebut untuk sebesar-besar kemakmuran rakyat, baik rakyat secara individual maupun rakyat sebagai anggota masyarakat hukum adat.

Pemberian hak kepada negara ini sejatinya merupakan bentuk penegasan bahwa tanah air Indonesia ini merupakan milik Negara Indonesia, bukan milik asing. Semangat lahirnya HMN dan UUPA masih kental dengan nuansa politik luar negeri yang menegaskan bahwa pihak asing tidak memiliki tanah di wilayah Indonesia. Semangat tersebut menguat bersamaan dengan semangat unifikasi hukum melalui UUPA dan menyerap hak-hak lain ke dalam sebuah terminologi HMN. Selanjutnya barulah HMN menurunkan kembali hak-hak individual dan komunal sebagai bagian darinya.

\section{PENUTUP}

\section{Simpulan}

Konsep Hak Menguasai Negara yang diatur dalam UUD 1945 dan UUPA, berbeda dengan hubungan hukum yang bersifat kepemilikan antara Negara dengan tanah berdasarkan asas Domeinverklaring yang diatur dalam Hukum Tanah Administrasi Pemerintahan Hindia Belanda yang telah dicabut dalam UUPA. Asas Domeinverklaring bertentangan dengan kesadaran hukum rakyat Indonesia dan asas dari Negara yang merdeka dan modern khususnya pada konstitusi UUD 1945 yang mengatur tentang penguasaan Negara terhadap seluruh sumber daya agraria pada hakikatnya diperuntukkan untuk sebesar-besarnya kemakmuran rakyat (Pasal 33 ayat (3)).

Dengan demikian dapat diketahui, meskipun negara diberi kewenangan (yang sangat luas) atas tanah, namun sesungguhnya dibatasi secara hukum untuk mewujudkan kemakmuran rakyat sesuai dengan tujuan berbangsa dan bernegara. Pengertian hak menguasai negara yang "dibatasi oleh hukum" dalam implementasinya oleh aparat penguasa, pengusaha terlebih lagi masyarakat belum memahami sepenuhnya makna yang terkandung dalamnya. Juga hal-hal yang menyangkut peraturan perundang-undangan yang tentang hak atas tanah dan pengelolaan sumber daya agraria. 
MK memberikan catatan penting mengenai dasar-dasar pengaturan dalam rangka pengalokasian dan pendistribusian sumber-sumber kehidupan bangsa untuk kesejahteraan: Dalam ketentuan konstitusional sebagai dasar-dasar pengaturan dalam rangka pengalokasian sumber-sumber kehidupan bangsa untuk kesejahteraan, termasuk di dalamnya sumber daya alam, seperti hutan, terdapat hal penting dan fundamental. Pertama, penguasaan Negara terhadap cabang produksi yang penting bagi negara dan yang menguasai hajat hidup orang banyak. Kedua, penguasaan negara terhadap bumi dan air dan kekayaan alam yang terkandung di dalamnya. Ketiga, penguasaan negara terhadap sumber daya tersebut, termasuk di dalamnya sumber daya alam, dimaksudkan supaya negara dapat mengatur dalam rangka pengelolaan terhadap sumber daya kehidupan tersebut untuk sebesar-besar kemakmuran rakyat, baik rakyat secara individual maupun rakyat sebagai anggota masyarakat hukum adat.

\section{Saran}

Memahami konsep hak menguasai Negara khususnya terhadap tanah sangat penting unuk diketahui supaya tidak salah konsepsi terhadap Negara atau pemerintah dalam menuntut hak-hak sebagai warga Negara.

\section{DAFTAR PUSTAKA}

Aminuddin Ilmar. (2012). Hak Menguasai Negara Dalam Privatisasi BUMN. Jakarta: Kencana Prenada Media Group

AP Parlindungan.(1991). Komentar Atas Undang-Undang Pokok Agraria. Bandung: PT Mandar Maju

Arie Sukanti Hutagalung dan Markus Gunawan. (2009). Kewenangan Pemerintah di Bidang Pertanahan. Jakarta: Rajawali Pers

Boedi Harsono. (200). Hukum Agraria Indonesia, Himpunan Peraturan-Peraturan Hukum Tanah. Jakarta: Djambatan.

Frans Magnis Soeseno dalam Ida Nurlinda. (2009). Prinsip-Prinsip Pembaharuan AgrariaPerspektif Hukum. Jakarta: Rajawali Pers.

Husen Alting. (2010). Dinamika Hukum Dalam Pengakuan Dan Perlindungan Hak Masyarakat Hukum Adat Atas Tanah (Masa Lalu, Kini, dan Masa Mendatang). Yogyakarta: LaksBang PRESSindo

Iman Soetiknjo. (1994). Politik Agraria Nasional (Hubungan Manusia Dengan Tanah Yang Berdasarkan Pancasila. Yogyakarta: Gadjah Mada University Press

Jasim Hamidi. (2011). Optik Hukum Peraturan Daerah Bermasalah (Menggagas Peraturan Daerah Yang Responsif dan Berkesinambungan). Jakarta: Prestasi Pustaka

Maria Rita Ruwiastuti. Sesat Pikir Politik Hukum Agraria. Yogyakarta: Press KPA dan Pustaka Belajar,

Maria SW. Soemardjono. (1998). Kewenangan Negara Untuk Mengatur Dalam Konsep Penguasaan Tanah Oleh Negara. Yogyakarta: Pidato Pengukuhan Jabatan Guru Besar Pada Fajultas Hukum Universitas Gadjah Mada.

Maria Sumardjono. (2009). Kebijakan Pertanahan, antara Regulasi dan Implementasi. Cetakan ke-VI, Edisi Revisi. Jakarta: Kompas Gramedia

Samun Ismaya. (2011). Pengantar Hukum Agraria. Yogyakarta: Graha Ilmu

Tody Sasmitha. (2014). Haryo Budhiawan, Sukayadi Laporan Penelitian Pemaknaan Hak Menguasai Negara Oleh Mahkamah Konstitusi (Kajian terhadap Putusan MK No. 35/PUU-X/2012; Putusan MK No. 50/PUUX/ 2012; dan Putusan MK No.3/PUUVIII/2010), Pusat Penelitian dan Pengabdian kepada Masyarakat. Sekolah Tinggi Pertanahan Nasional. Cetakan Pertama, Desember 2014

Yamin, Abdul Rahim Lubis. (2008). Hukum Pendaftaran Tanah. Mandar Maju. Cetakan-I,

Konsorsium Reformasi Hukum Nasional ( KRHN ), dan Konsorium Pembaruan Agraria, usulan revisi UndangUndang Pokok Agraria, Menuju Penegakan Hak-Hak Rakyat Atas Sumber Agraria.

Kamus Besar Bahasa Indonesia. (1998). Departemen Pendidikan Dan Kebudayaan Republik Indonesia. Jakarta. 